\title{
Logical Form of Hierarchical Relation on Verbs and Extracting it from Definition Sentences in a Japanese Dictionary
}

\author{
Yoichi TOMIURA *, Teigo NAKAMURA *, \\ Toru HITAKA * and Sho YOSHIDA ** \\ * Department of Computer Science and Communication Engineering, Kyushu University \\ Fukuoka, 812, JAPAN \\ ** Department of Artificial Intelligence, Kyushu Institute of Technology \\ lizuka, 820, JAPAN
}

\begin{abstract}
We are studying how to extract hierarchical relation on verbs from definition sentences in a Japanese dictionary. The hierarchical relation on verbs has been dealt with as a binary relation on verbs, but it should be dealt with as logical relation on predicates. We will define the logical form of the hierarchical relation on verbs and then discuss which part of the syntactic structure of the definition sentence represents that relation. We will call the main predicate verb in this part the definition verb. Furthermore we will describe how to semiautomatically select the proper meaning of the definition verb and the proper correspondence between cases of an entry verb and the definition verb in order to extract the hierarchical relation as logical relation.
\end{abstract}

\section{Introduction}

The syntactic processing has been playing the main role in a natural language processing system. But we have come to know that we can't construct a practical system with only this processing and that the semantic processing is necessary for it. Inference plays an important role in the semantic processing, we therefore need a large knowledge base about meaning of words and we must treat it as logical relation.

Hierarchical relation between words is in- evitable and transitive, and it is a important relation in the large knowledge base. Because inevitable relation holds at any time and the reliability of conclusions inferred from it doesn't fall down and transitive relation can be described efficiently.

There were some researches on extracting the hierarchical relation between words from definition sentences in a ordinary dictionary[1][2][3][4]. But they treated it as only binary relation between words. Verbs correspond to n-ary predicates on entities and we therefore must describe the correspondence between the variables (that is case or syntactic role) of a subordinate verb and ones of its superordinate verb. But this correspondence can't be described if the relation is treated as binary relation between words.

We will propose how to extract the hierarchical relation with a logical form on verbs from definition sentences in a Japanese dictionary. Firstly, we will define the logical form of the hierarchical relation on verbs and then discuss which part of the syntactic structure of the definition sentence represents that relation. We will call the main predicate verb in this part the definition verb. Secondly, we will describe how to semiautomatically select the proper meaning of the definition verb and the proper correspondence between the variables of an entry verb and ones of the definition verb. Lastly, we will report about the result of a experiment to extract the 
hierarchical relation from the machine readable dictionary IPAL.

A verb will be corresponded to the n-ary predicate according to a pattern of cases (syntactic roles). Considering the polysemy of verbs, each meaning of a single verb must correspond to the distinct predicate. For example, “雾する”(love) as first meaning is used with the form of " $x_{1}$ 加

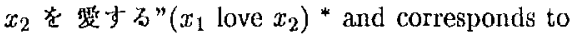
“戏する $1\left(x_{1}, x_{2}\right)$ '.

Furthermore, we will not deal with intensional verbs in this paper.

\section{Logical Form of Hierarchical Relation on Verbs}

Verbs correspond to predicates on entities. If $V^{L}\left(\eta_{1}, \cdots, \eta_{n}\right)$ is the subordinate predicate of $V^{U}\left(\xi_{1}, \cdots, \xi_{m}\right)$, both predicates have the same arity (i.e. $m=n$ ), there is a one-to-one correspondence $\psi$ from $\{1, \cdots, n\}$ to $\{1, \cdots, n\}$, and if $V^{L}\left(\xi_{1}, \cdots, \xi_{n}\right)$ is true, $V^{U}\left(\xi_{\psi(1)}, \cdots, \xi_{\psi(n)}\right)$ is also true at the same time. That is,

$$
\forall \boldsymbol{x}\left[V^{L}(\boldsymbol{x}) \supset V^{U}(\boldsymbol{x})\right],
$$

where boldface $\boldsymbol{x}$ stands for a tuple of variables. Strictly speaking, the logical form of the hierarchical relation on verbs is (1).

For example, "fo $t_{1}$ " is the subordinate verb of “接取する,. To describe this logically,

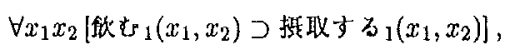

where '领 $t_{1}\left(\eta_{1}, \eta_{2}\right)$ ' means that $\eta_{1}$ drink $\eta_{2}$ and

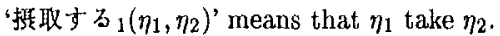

But there are $v^{L}$ and $v^{U}$ such that some arguments in $V^{L}\left(\eta_{1}, \cdots, \eta_{n}\right)$ don't correspond to any arguments in $V^{U}\left(\xi_{1}, \cdots, \xi_{m}\right)$ or some in $V^{U}\left(\xi_{1}, \cdots, \xi_{m}\right)$ don't correspond to any arguments in $V^{L}\left(\eta_{1}, \cdots, \eta_{n}\right)$, although $v^{L}$ is a subordinate verb of $v^{U}$. In this case, we conclude that the predicate denoted by $\exists y V^{L}(x, y)$ is a subordinate one of the predicate denoted by $\exists z V^{U}(x, z)$. Therefore, by generalizing (1), we get

"Syntactic role is represented by means of a postposition, such as " $\not$ " and “t", in Japanese.

$$
\forall \boldsymbol{x}\left[\exists \boldsymbol{y} V^{I}(\boldsymbol{x}, \boldsymbol{y}) \supset \exists z V^{U}(\boldsymbol{x}, \boldsymbol{z})\right],
$$

that is,

$$
\forall x y \exists z\left[V^{L}(\boldsymbol{x}, \boldsymbol{y}) \supset V^{U}(\boldsymbol{x}, z)\right] .
$$

We expand (2) further to restrict the domain of $z$, and define the logical form of the hierarchical relation on verbs as follows.

Deflnition $1 v^{L}$ is a subordinate verb of $v^{u}$, if for some $N$

$$
\forall x y \exists z\left[V^{L}(x, y) \supset N(z) \wedge V^{U}(\boldsymbol{x}, z)\right],
$$

where boldface $N$ stands for a tuple of predicate letters and $N(z)$ means $N_{1}\left(z_{1}\right) \wedge \cdots \wedge N_{n}\left(z_{n}\right)$.

A small letter, such as $n, v$, and $v^{L}$, stands for a linguistic expression and a capital letter, such as $N, V$, and $V^{L}$, stands for the predicate symbol corresponding to the linguistic expression represented by its small letter.

For example, “洞 j, is a subordinate verb of “帯び $\beth_{1}$ " because the following formula holds,

$$
\begin{aligned}
& \forall x y \exists z[\text { 潤う } 1(y, x) \supset \\
& \quad \text { 水分 }(z) \wedge \text { 带びる } 1(x, z)],
\end{aligned}
$$

where

濢 ${ }_{1}\left(\eta_{1}, \eta_{2}\right) \quad: \eta_{2}$ is irrigated by $\eta_{1}$,

水分 $(\eta): \eta$ is moisture,

带びる $\left(\eta_{1}, \eta_{2}\right): \eta_{1}$ take on $\eta_{2}$.

\section{Extraction}

\subsection{Extracting the Hierarchical Ex- pression in a Deflnition Sentence}

Deflnition 2 The relation between an entry verb $v^{e}{ }^{\dagger}$ and its definition sentence $s$ is

$$
\forall x\left[\exists y V^{e}(x, y) \equiv \exists z S(x, z)\right] .
$$

For example, the definition sentence for "觓 $t_{1}$ "(drink) is “蛈物を摄取する and the definition sentence for “调方” is “水分 をたっぶりと带びる。” (to take on moisture fully). We get

\footnotetext{
${ }^{\dagger}$ For convenience, we will omit the number of the meaning of an entry verb.
} 


$$
\begin{aligned}
& \forall x_{1} x_{2}\left[\text { 领 } t_{1}\left(x_{1}, x_{2}\right) \equiv\right. \\
& \text { 欱物 } \left.\left(x_{2}\right) \wedge \text { 摄取する } 1\left(x_{1}, x_{2}\right)\right] \text { ， } \\
& \forall x\left[\exists y \text { 潤う }{ }_{1}(u, x) \equiv\right. \\
& \exists z[\text { 水分 }(z) \wedge \text { たっぶりと带びる } 1(x, z)]] \text {, }
\end{aligned}
$$

where

$$
\begin{aligned}
& \text { 炏を }\left(\eta_{1}, \eta_{2}\right) \quad: \eta_{1} \text { drink } \eta_{2} \text {, } \\
& \text { 觓物 }(\eta) \quad: \eta \text { is a drink, } \\
& \text { 㧴取する }\left(\eta_{1}, \eta_{2}\right) \text { : } \eta_{1} \text { take } \eta_{2} \text {, } \\
& \text { 洞 } \eta_{1}\left(\eta_{1}, \eta_{2}\right) \quad: \eta_{2} \text { is irrigated by } \eta_{1} \text {, } \\
& \text { 水分 }(\eta): \eta \text { is moisture, } \\
& \text { たっふりと带びる } 1\left(\eta_{1}, \eta_{2}\right) \text { : } \\
& \eta_{1} \text { take on } \eta_{2} \text { fully. }
\end{aligned}
$$

We call the main predicate verb of a definition sentence the definition verb. If the definition sentence of a entry verb $v^{e}$ corresponds to

$$
N(\eta) \wedge V^{d}(\eta)
$$

then we can easily derive the hierarchical relation between $v^{e}$ and its definition verb $v^{d}$ from Definition 2. In this paragraph, we assume that the meaning of the definition verb has been selected correctly and we will omit the number of the meaning of definition verbs. How to select it will be given in $\mathbf{3 . 2}$.

A definition sentence does not always correspond to the logical form as (3). But if we can get the sentence $s^{d}$ which is a part of the definition sentence $s$ and corresponds to the logical form as (3) and $S \supset S^{d}$, then we can also derive the hierarchical relation between the entry verb and the definition verb. We call $s^{d}$ the hierarchical expression in a definition sentence (HED). Now, we will discuss which part of the syntactic structure of the definition sentence is HED.

Deflnition 3 We get rid of modifiers out of a simple sentence $s$. We call the rest of $s$ the kernel sentence $s^{k}$ of $s$.

Since there isn't a expression corresponding to a universal quantifier in the definition sentence of a verb, we can conclude the following characteristic.

Characteristic 1 If $s^{k}$ is the kernel sentence of a simple sentence $s$, then $S \supset S^{k}$ and the logical form of $S^{k}$ is (3).
For example, the kernel sentence of “体の痛み 孝一時的に消与”(to kill a pain in the body temporally) is “痛みを消す”(to kill a pain) and its logical form is

$$
\text { 痛以 }\left(\eta_{2}\right) \wedge \text { 消す }\left(\eta_{1}, \eta_{2}\right) \text { ， }
$$

and the following formula holds,

$$
\begin{aligned}
& \forall \eta_{1} \eta_{2} \eta_{3}\left[S\left(\eta_{1}, \eta_{2}, \eta_{3}\right) \supset\right. \\
& \text { 病み } \left.\left(\eta_{2}\right) \wedge \text { 消寸 }\left(\eta_{1}, \eta_{2}\right)\right],
\end{aligned}
$$

where $S\left(\eta_{1}, \eta_{2}, \eta_{3}\right)$ is the formula corresponding to “体の痛み一特的に消す” and means that $\eta_{2}$ is a pain, $\eta_{3}$ is a body, and $\eta_{1}$ kill $\eta_{2}$ in $\eta_{3}$ temporally. '解み $(\eta)$ ' means that $\eta$ is a pain. ' 消す $\left(\eta_{1}, \eta_{2}\right)$ ' means that $\eta_{1}$ kill $\eta_{2}$.

There is a sentence $s$ which satisfies the following characteristic.

Characteristic 2 A sentence s includes a sentence $s^{\prime}$ and $S \supset S^{\prime}$.

If the definition sentence $s$ of a verb is complex, then $s$ satisfies Characteristic 2 and $s^{\prime}$ is its main clause. For example, the main clause of the sentence “何かががさるように付着する” (something adheres to $X$ as it covers $X$ ) is “何办 加付着する"(something adheres to), and it corresponds to the following formula,

$$
\text { 何か }\left(\eta_{1}\right) \wedge \text { 付着する }\left(\eta_{1}, \eta_{2}\right) \text { ， }
$$

and the following formula holds,

$$
\begin{aligned}
& \forall \eta_{1} \eta_{2}\left[S\left(\eta_{1}, \eta_{2}\right) \supset\right. \\
& \left.\quad \text { 何加 }\left(\eta_{1}\right) \wedge \text { 付着する }\left(\eta_{1}, \eta_{2}\right)\right],
\end{aligned}
$$

where $S\left(\eta_{1}, \eta_{2}\right)$ is the formula corresponding to “何加加恕さるように付着する” and means that something $\eta_{1}$ adhere to $\eta_{2}$ as $\eta_{1}$ covers $\eta_{2}$, '何加 $(\eta)$ ' means that $\eta$ is something, and '付着する $\left(\eta_{1}, \eta_{2}\right)$ ' means that $\eta_{1}$ adhere to $\eta_{2}$.

Meaning of the compound sentence $s$, in which two sentences $\left(s_{1}, s_{2}\right)$ are connected by a conjunction corresponding to 'and' in English, is either ' $S_{1} \wedge S_{2}$ ' or 'after $S_{1}, S_{2}$ '. Therefore, an operator needs to decide the relation between $s_{1}$ and $s_{2}$. In the former case, $s$ satisfies Characteristic 2 and $s^{\prime}$ can be both $s_{1}$ and $s_{2}$. For example, a sentence “何かを投げて慗いよく接触 させる" (to throw something and have it touched 
hard) consists of two sentences. One is "何か 投げる” (to throw something), the other is “势w 上く接触させる” (to have it touched hard), and two sentences correspond to following formulae respectively,

$$
\begin{aligned}
& \text { 何か }\left(\eta_{2}\right) \wedge \text { 投げる }\left(\eta_{1}, \eta_{2}\right), \\
& \text { 䓡いよく接螌させる }\left(\eta_{1}, \eta_{2}, \eta_{3}\right) .
\end{aligned}
$$

And two sentences are simultaneous. So following formulae hold,

$$
\begin{aligned}
& \forall \eta_{1} \eta_{2} \eta_{3}\left[S\left(\eta_{1}, \eta_{2}, \eta_{3}\right) \supset\right. \\
& \text { 们加 } \left.\left(\eta_{2}\right) \wedge \text { 投げる }\left(\eta_{1}, \eta_{2}\right)\right] \text {, } \\
& \forall \eta_{1}, \eta_{2} \eta_{3}\left[S\left(\eta_{1}, \eta_{2}, \eta_{3}\right) \supset\right. \\
& \text { 莓いよく接触させる }\left(\eta_{1}, \eta_{2}, \eta_{3}\right) \text {, }
\end{aligned}
$$

where $S\left(\eta_{1}, \eta_{2}, \eta_{3}\right)$ is the formula corresponding to “何かを投げて憼い上く接触させる” and means that $\eta_{1}$ throw $\eta_{2}$ and have $\eta_{2}$ touched hard to $\eta_{3}$. '何 げる $\left(\eta_{1}, \eta_{2}\right)$ ' means that $\eta_{1}$ throw $\eta_{2}$. ‘勢い上 く接触させる $\left(\eta_{1}, \eta_{2}, \eta_{3}\right)$ ' means that $\eta_{1}$ have $\eta_{2}$ touched hard to $\eta_{3}$.

To apply Characteristic 2 repeatedly, we conclude that there is a definition sentence $s$ which include a simple sentence $s^{\prime}$ and $S \supset S^{\prime}$ and that the kernel sentence of $s^{\prime}$ is HED. For example, the sentence $s$ “あるものをまっすぐにす るためにその物の耐端を持って雨方河に力を加之 $z$ " (to hold both ends of something and apply force to both sides in order to make it straight) is complex. It therefore satisfies Characteristic 2 and $S \supset S_{1}$, where $s_{1}$ is its main clause "₹の 物の两端を持って舒方向に力を㧈之る”（to hold both ends of something and apply force to both sides). $s_{1}$ is a compound sentence and is composed of $s_{2}$ “その物の两端を持つ” (to hold both ends of something) and $s_{3}$ “両方们に力を加之る” (to apply force to both sides) and two sentence is simultaneous. $s_{1}$ therefore satisfies Characteristic 2 and $S_{1} \supset S_{2}$ and $S_{1} \supset S_{3}$. Therefore, $S \supset S_{2}$ and $S \supset S_{3}$. Because $s_{2}$ and $s_{3}$ are simple sentences, the kernel sentences of $s_{2}$ and $s_{3}$ are HEDs. When the definition sentence is simple, its kernel sentence is HED.

If we decide the proper meaning of the definition verb and the proper correspondence from cases of $v^{e}$ to cases of $v^{d}$ correctly, we conclude

$$
\begin{aligned}
& \vee x y \exists z\left[V^{e}(x, y) \supset\right. \\
& \left.\quad N_{x}(x) \wedge N_{x}(z) \wedge V^{d}(x, z)\right] .
\end{aligned}
$$

We can get a hierarchical relation between $v^{\varepsilon}$ and $v^{d}$ as follows from (4),

$$
\forall x y \exists z\left[V^{e}(x, y) \supset N_{z}(z) \wedge V^{d}(x, z)\right] .
$$

\subsection{Necessary Condition and Heuris- tic}

In this paragraph we supposed that an entry verb $v^{e}$ has HED.

What we call the selectional restriction has been used to narrow down candidates for syntactic structure in the syntactic processing. It is the restriction about the semantic category of a noun phrase which a certain verb can take as a certain case. The semantic category has been called the semantic marker or semantic primitive. For example, semantic categories of the subjective noun phrase and the objective noun phrase for the verb "饮 mal' and 'liquid' respectively. We use this information to semiautomatically select the proper meaning of $v^{d}$ and the proper correspondence from cases of $v^{e}$ to cases of $v^{d}$. The information is mentioned in the Japanese dictionary we used for the experiment of extraction.

The restriction that if a verb $v_{k}$ can take a noun phrase with a case $c$ the semantic category of the noun phrase is $D$ is expressed logically as follows,

$$
\forall x\left[V_{k}(x) \supset D\left(x_{i}\right)\right],
$$

where $x_{i}$ is the argument corresponding to the case $c$, and $k$ is the meaning number of $v$. We call $D$ in (5) the domain for $c$ of $v_{k}$. For example,

$$
\begin{aligned}
& \forall \eta_{1} \eta_{2} \text { [钦动 }{ }_{1}\left(\eta_{1}, \eta_{2}\right) \supset \\
& \left.\operatorname{animal}\left(\eta_{1}\right) \wedge \operatorname{liquid}\left(\eta_{2}\right)\right] \text {, }
\end{aligned}
$$

where '觓 $t_{1}\left(\eta_{1}, \eta_{2}\right)$ ' means that $\eta_{1}$ drink $\eta_{2}$.

If the semantic category of a noun $n$ is $D$,

$$
\forall x[N(x) \supset D(x)] \text {. }
$$

We call $D$ in (6) the domain for $n$.

If the $\mathrm{k}$-th meaning is proper as $v^{d}$ in the definition sentence of $v^{e}$ and the correspondence from $\mathrm{i}$-th case of $v^{e}$ to $\mathrm{j}$-th case of $v_{k}^{d}$ is correct, then the following formula holds, 


$$
\begin{gathered}
i \\
\downarrow \\
\forall \cdots x \cdots\left[V^{e}(\cdots, x, \cdots) \supset\right. \\
\left.\cdots \wedge N(x) \wedge \cdots \wedge V_{k}^{d}(\cdots, \underset{\uparrow}{x}, \cdots)\right] .
\end{gathered}
$$

Assumption 1 We assume $\exists \boldsymbol{x} V(x)$ is true for each verb $v$ and $\exists x N(x)$ is true for each noun $n$.

We conclude

$$
\exists x\left[D^{e}(x) \wedge D^{n}(x) \wedge D^{d}(x)\right]
$$

from $\exists \boldsymbol{x} V^{e}(\boldsymbol{x})$ (Assumption 1) and (7), where

$$
\begin{aligned}
& \forall \eta\left[V^{e}\left(\cdots, \eta_{i}, \cdots\right) \supset N^{e}\left(\eta_{i}\right)\right], \\
& \forall \eta\left[V_{k}^{d}\left(\cdots, \eta_{j}, \cdots\right) \supset N^{d}\left(\eta_{j}\right)\right], \\
& \forall \eta\left[N(\eta) \supset D^{n}(\eta)\right] .
\end{aligned}
$$

We establish (8) as the necessary condition in which the correspondence is valid. We check (8) with $\exists x N(x)$ (Assumption 1) and the relation between domain predicates.

Necessary Condition If the $k$-th meaning is proper as $v^{d}$ in the definition sentence of $v^{e}$ and the correspondence from $i$-th case of $v^{e}$ to $j$-th case of $v_{k}^{d}$ is correct, then

$$
\exists x\left[D^{e}(x) \wedge D^{n}(x) \wedge D^{d}(x)\right],
$$

where $D^{e}$ is the domain for $i$-th case of $v^{e}$ and $D^{d}$ is one for $j$-th case of $v_{k}^{d}$ and the noun of $j$-th case of $v_{k}^{d}$ in the definition sentence is $n$ and the domain for $n$ is $D^{n}$.

The meaning of an entry verb $v^{e}$ is defined by using the definition verb $v^{d}$. Then, the less the number of the variables appearing either only in $v^{e}$ or only in $v^{d}$ (i.e. (size of tuple $y$ ) + (size of tuple $z$ ) in the formula (4) ), the more $v^{d}$ restricts the meaning of $v^{c}$. An editor of a dictionary would select such a definition verb. We therefore establish the following heuristic.

Heuristic The less the number of the variables appearing either only in $v^{e}$ or only in $v_{k}^{d}$, the more we have chance of correct selection for meaning of $v^{d}$ and the correspondence of the variables.

\subsection{Example of Extraction}

In this paragraph the method how to extract the hierarchical relation on verbs will be introduced. We suppose following definitions about “爱する” and “持つ”。

露する

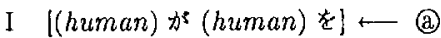
とても好きだという気持ちを持つ.(to experience a strong feeling of fondness) .........

持》

I [(human) 加 (hand) に (concrete) 手に何加范持つ. (to have something with one's hand) II [(human) が (human)に (mental) 睢加に対してある感情を抱く. (to experience a feeling toward somebody)

III [(all_entities) $x^{*}$ (abstract) 何らかの属性や設䚚を有する。 (to have some property or equipment)

(a)means that "敩する “ $n p_{1}$ が $n p_{2}$ をする” and the semantic category of $n p_{1}$ and $n p_{2}$ must have 'human'. We get the following knowledge about domain of words.

$$
\begin{aligned}
& \forall \eta\left[\begin{array}{c}
\text { 要す } \\
1
\end{array}\left(\eta_{1}, \eta_{2}\right) \supset\right. \\
& \left.\operatorname{human}\left(\eta_{1}\right) \wedge \operatorname{human}\left(\eta_{2}\right)\right] \text {, } \\
& \forall \eta\left[\text { 持つ } 1\left(\eta_{1}, \eta_{2}, \eta_{3}\right) \supset \mid \operatorname{human}\left(\eta_{1}\right) \wedge\right. \\
& \left.\left.\wedge \text { hand }\left(\eta_{2}\right) \wedge \text { concreat }\left(\eta_{3}\right)\right]\right] \text {, } \\
& \forall \eta\left[\text { 持 } \supset _ { 2 } ( \eta _ { 1 } , \eta _ { 2 } , \eta _ { 3 } ) \supset \left\lfloor\text { human }\left(\eta_{1}\right) \wedge\right.\right. \\
& \left.\left.\wedge \operatorname{human}\left(\eta_{2}\right) \wedge \operatorname{mental}\left(\eta_{3}\right)\right]\right] \text {, } \\
& \forall \eta\left[\text { 持 } \supset_{3}\left(\eta_{1}, \eta_{2}\right) \supset\right. \\
& \text { all_entities } \left.\left(\eta_{1}\right) \wedge \text { abstract }\left(\eta_{2}\right)\right] \text {, } \\
& \forall \eta[\text { 気持ち }(\eta) \supset \operatorname{mental}(\eta)] \text {. }
\end{aligned}
$$

'all_entities' expresses the set of all entities. We suppose the following relation between domain predicates,

$$
\begin{aligned}
& \forall \eta[\text { human }(\eta) \vee \text { hand }(\eta) \supset \text { concrete }(\eta)], \\
& \forall \eta[\text { mental }(\eta) \supset \text { abstract }(\eta)], \\
& \forall \eta[\text { concrete }(\eta) \vee \text { abstract }(\eta) \supset \\
& \quad \text { all_entities }(\eta)], \\
& \neg \exists \eta[\text { concrete }(\eta) \wedge \text { abstract }(\eta)], \\
& \neg \exists \eta[\operatorname{human}(\eta) \wedge \operatorname{hand}(\eta)] .
\end{aligned}
$$

We parse the definition sentence "とても好き だという気持ちを持つ” for the entry verb “愛す 
$z_{1} "$, and we find this sentence is simple and its kernel sentence “烒持ち持っ” is HED. We narrow down candidates for the meaning of the definition verb “持つ” on parsing by selectional restriction. Meanings of “持っ" that satisfy selectional restriction are II and III. Since we can infer

$$
\exists x[h u m a n(x) \wedge \text { all_entities }(x)]
$$

from Assumption 1 and the relation between domain predicate, the correspondence from the

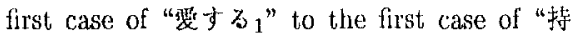
$\supset 3$ "satisfies the necessary condition described in paragraph 3.2. Since we can infer

$$
\neg \exists x[\text { human }(x) \wedge \text { mental }(x) \wedge \operatorname{abstract}(x)],
$$

the correspondence from the first case of "傮 万 1" to the second case of “持つ 3 "does not satisfy the necessary condition. After all, for “持 $\supset_{2}$ " and “持つ另", partial one-to-one correspondences which satisfy the necessary condition are

$$
\begin{aligned}
& \text { 持口 } 2: a .\{\} \text {, } \\
& \text { b. }\{<1,1>\}, \quad \text { c. }\{<1,2>\} \text {, } \\
& \text { d. }\{<2,1>\}, \quad \text { e. }\{<2,2>\} \text {, } \\
& \text { f. }\{<1,1>,<2,2>\} \text {, } \\
& \text { g. }\{<1,2>,<2,1>\} \text {, } \\
& \text { 持别: h. }\{\} \text {, } \\
& \text { i. }\{<1,1>\}, \quad j .\{<2,1>\} \text {, }
\end{aligned}
$$

For example, the correspondence $g$ means that the first case of "㩆 second case of "持 $\supset_{2}$ " and the second case of “浽与 $\partial_{2}$ ".

Because the number of the variables which appear either only in the entry verb or in the defnition verb for the correspondence $g$ is 1 and onc for the correspondence $i$ is 2 , the pair of "持 $\supset_{2}$ " and the correspondence $g$ is prior to the pair of “持つ, and the correspondence $i$ by the heuristic. The pair of "持 $\supset_{2}$ " and the correspondence $f$ and the pair of “持 $\supset_{2}$ and the correspondence $g$ are given the highest priority by the heuristic after all.

It is decided by a operator that the second meaning of 持a and the correspondence $f$ are proper, and we get

$$
\begin{aligned}
& \forall x \exists z \mid y_{1}
\end{aligned}
$$

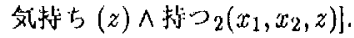

\section{Experiment of Extraction}

We have experimented on extracting the hierarchical relation using the machine-readable dictionary IPAL (IP $\Lambda$ : Information-technology Promotion Agency, Japan; IPAL : IPA Lexicon of the Japanese language for computers). 861 verls and 3379 meanings are contained in this dictionary. 'The definition sentence of an entry verb and the jattern of cases for the entry verb and the domain for each of the cases of the entry verb are given in this dictionary (see $A$ ppendix). $\Lambda$ nd we can also get the domain for a noun from this dictionary.

We made a lexical functional grammar which outputs the logical form of HED as a feature. We parsed the definition sentences and got 1709 HEDs whose main predicate verb are given as an entry verb in this dictionary with this grammar. We have extracted the hierarchical relations on verbs from 1288 IIEDs. The average number of candidates which are given the highest priority by the heuristic described in paragraph 3.2 is 4.6 and there is the correct solution in 4.6 candidates at the rate of $70.4 \%$. The num. ber of meanings of verbs in the highest layer in the hierarchy is 288 , and the average level in the hierarchy is 2.7. Maybe this value is so little. We think in this point since II'AL is a basic verb dictionary its entry verbs are in a comparatively high ordinate in hierarchy of all verbs.

\section{Conclusion}

We have defined the logical form of the hierarchical relation on verbs and have described how to extract it from definition sentences in a Japanese dictionary.

The incthod described in this paper is for a Japanese dictionary, but it can be applied to other languages dictionary, too. 


\section{Reference}

[1] Robert A. Amsler, A Taxonomy for English Nouns and Verbs, Proc. of the 19th Annual Meeting of the ACL pp.133-138, 1981

[2] H. Tsurumaru, T. Hitaka, S. Yoshida, An Attempt to Automatic Thesaurus Construction from an Ordinary Japanese Language Dictionary, Proc. of COLING'86, pp.445-447, 1986

[3] J. Nakamura, M. Nagao, Extraction of Semantic Information from an Ordinary English Dictionary and its Evaluation, Proc. of COL$I N G^{\prime} 88$, pp.459-464, 1988

[4] Louise Guthrie, Brian M. Slator, Yorick Wilks, ReBecca BRuce, Is There Content in Empty Heads ?, Proc. of COLING'go, pp.138143,1990

[5] Y. Tomiura, T. Hitaks, S. Yoshida, Extracting Superordinate-subordinate Relation between Verbs from Definition Sentence in Japanese Dictionary, Information Processing Society of Japan, Natural Language Special Interest Group Technical Report, No.73-9, pp.1724, 1989, (in Japanese)

\section{Appendix}

\section{A.1 Example of Contents of IPAI}

（見出し〉80 〈通翻〉 001

〈N o〉005〈枚数〉012〈意味〉何小に対 して、ある感情老抱く。〈類载〉抱く(分名 1) (感賞・㝿労・睡眼なと)〈分番 1) $(2 ， 300)$ 〈分名 2〉(感想)(分翻 2 〉(411b)〈意味分

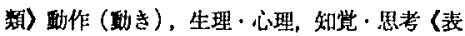
䟕）持（b）っ〈活用〉五段〈語幹〉 mot (自 他〉他〈派可〉るてる〈派使〉もたす〈文型〉N 1 ガ $\mathrm{N} 2=\mathrm{N} 3$ \%〈文1〉私生特来に 希望老 持っている。〈文2〉彼は相手のやり

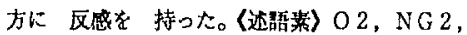
O ]〈格1〉ガ〈慗 I〉HUM/ORG (名 1) 彼／政府〈格2〉二〈慗2〉CON/ABS〈名 2)自分、彼女、新人、相手国、本、北、山/生

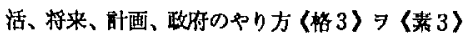

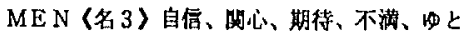

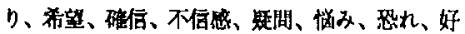

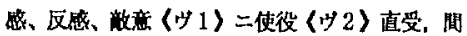

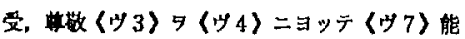
助〈テ 1) 未来〈テ 2〉結果残有〈テ 3〉テシマ ウ, カケル, ハシメル, タス, ッッケル〈ム1〉

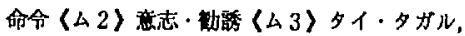
ナサイ, ナ(禁止) (ム 4) 3 a (マナ) マス, ナ 1〈惯用〉根に〜。 $\langle\ldots\rangle$ expresses what the filed following it means. ' $b \supset$ ' is a entry. '持 $\supset$ ' is the notation of the entry with Chinese character. '何加に対 して，ある感情を抢く。' is a definition sentence. ' 005 ' following $\left.\left\langle\mathrm{N}_{0}\right\rangle\right\rangle$ represents the definition sentence corresponds the fifth meaning of 60 (持っ)'. The Japanese word following 〈格 $i$ \rangle and symbols following 〈素 $i\rangle$ represent a pattern of the cases for 持 $\partial_{5}$ and the domain for each case of the verb. That is, '持 $\supset_{5}$ ' is used with the form ' $N P_{1}$ 出 $N P_{2}$ に $N P_{3}$ t持つ', and the semantic category of $N P_{1}$ is 'human' or 'organization', and one of $N P_{2}$ is 'concrete object' or 'abstract object', and one of $N P_{3}$ is 'mental object'. We can get

$$
\begin{aligned}
& \forall x\left[\text { 持つ } \supset_{5}\left(x_{1}, x_{2}, x_{3}\right) \supset\right. \\
& {\left[\text { human }\left(x_{1}\right) \vee \text { organization }\left(x_{1}\right)\right] \wedge} \\
& {\left[\text { concrete }\left(x_{2}\right) \vee \text { abstract }\left(x_{2}\right)\right] \wedge} \\
& \text { mental } \left.\left(x_{3}\right)\right]
\end{aligned}
$$

from these informations. Japanese words following 〈名 $i\rangle$ are example of $N P_{i}$. We can get the domain for nouns from these informations. For example, we can get

$$
\forall x[\text { 政府 }(x) \supset \operatorname{organization}(x)] \text {, }
$$

where '政府' means 'government'. We used the above informations.

\section{A.2 A Example of Extracted Rela- tions}

$$
\begin{aligned}
& \text { 示寸 } y_{3}\left(x_{1}, y, x_{2}, x_{3}\right) \supset \text { 表わす } 3\left(x_{1}, x_{2}, x_{3}\right) \\
& \text { 出子 } 17\left(x_{1}, x_{2}, y\right) \supset \\
& \text { ヨ } x\left[[\text { Lぐさ }(z) \vee \text { 表情 }(z)] \wedge \text { 表加す } 3\left(x_{1}, x_{2}, z\right)\right] \\
& \text { 嗼 } \\
& \text { 揭げ } 3\left(x_{1}, x_{2}\right) \supset \exists z \text { 示す } 3\left(x_{1}, z_{1}, x_{2}, z_{2}\right)
\end{aligned}
$$

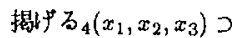

$$
\begin{aligned}
& \exists z\left[\text { 人 }(z) \wedge \text { 示 } y_{3}\left(x_{1}, z, x_{3}, x_{2}\right)\right] \\
& \text { 表わす } 2\left(x_{1}, x_{2}, x_{3}\right) \supset \text { 出す }{ }_{17}\left(x_{1}, x_{2}, x_{3}\right) \\
& \text { 渴らす } 2\left(x_{1}, x_{2}, y\right) \text { つ } \\
& \exists z\left[[\text { 声 }(z) \vee \text { 表情 }(z)] \wedge \text { 出す }{ }_{17}\left(x_{1}, z, x_{2}\right)\right] \\
& \text { 示す } 2\left(x_{1}, x_{2}, x_{3}\right) \supset \text { 表わす } 2\left(x_{1}, x_{2}, x_{3}\right) \\
& \text { 見せる } 10\left(x_{1}, x_{2}, x_{3}\right) \supset \text { 示す } 2\left(x_{1}, x_{2}, x_{3}\right)
\end{aligned}
$$

